\title{
Dental anomalies inside the cleft region in individuals with nonsyndromic cleft lip with or without cleft palate
}

\author{
Jamile Sá ${ }^{1}$, Luana Araújo ${ }^{1}$, Laís Guimarães ${ }^{1}$, Samário Maranhão ${ }^{1}$, Gabriela Lopes ${ }^{1}$, Alena Medrado ${ }^{1}$, Ri- \\ cardo Coletta $^{2}$, Silvia Reis ${ }^{1}$
}

\author{
${ }^{1}$ Department of Basic Science, Bahiana School of Medicine and Public Health, Salvador, Bahia, Brazil \\ ${ }^{2}$ Department of Oral Diagnosis, School of Dentistry, State University of Campinas, Piracicaba, São Paulo, Brazil
}

Correspondence:

Department of Basic Science

Bahiana School of Medicine and Public Health

Av. Silveira Martins, no 3386, Cabula

CEP: 41150-100, Salvador, Bahia, Brazil

srareis@bahiana.edu.br

Sá J, Araújo L, Guimarães L, Maranhão S, Lopes G, Medrado A, Coletta $\mathrm{R}$, Reis S. Dental anomalies inside the cleft region in individuals with nonsyndromic cleft lip with or without cleft palate. Med Oral Patol Oral Cir Bucal. 2016 Jan 1;21 (1):e48-52.

http://www.medicinaoral.com/medoralfree01/v21i1/medoralv21i1p48.pdf

Received: 05/04/2015

Accepted: 07/08/2015

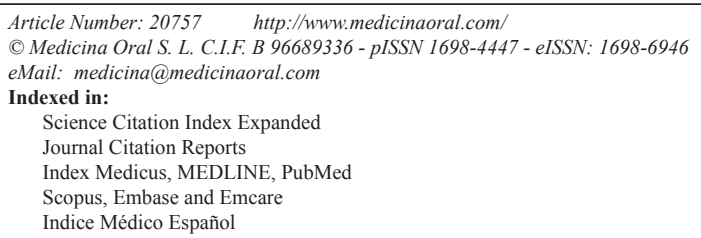

\begin{abstract}
Background: Individuals with nonsyndromic cleft lip with or without cleft palate (NSCL \pm P) present high frequency of dental anomalies, which may represent complicating factors for dental treatment. The aim of this study was to investigate the prevalence of dental anomalies inside cleft area in a group of Brazilians with NSCL \pm P.

Material and Methods: Retrospective analysis of 178 panoramic radiographs of patients aged from 12 to 45 years old and without history of tooth extraction or orthodontic treatment was performed. Association between cleft type and the prevalence of dental anomalies was assessed by chi-square test with a significance level set at $p \leq$ 0.05 .

Results: Dental anomalies were found in $88.2 \%(\mathrm{n}=157)$ of the patients. Tooth agenesis $(47.1 \%)$, giroversion $(20 \%)$ and microdontia $(15.5 \%)$ were the most common anomalies. Individuals with unilateral complete cleft lip and palate (CLP, $p<0.0001)$, bilateral complete CLP $(p=0.0002)$ and bilateral incomplete CLP $(p<0.0001)$ were more affected by tooth agenesis than individuals with other cleft types. The maxillary lateral incisors were the most affected teeth $(p<0.0001)$.

Conclusions: The present study revealed a high frequency of dental anomalies inside cleft region in NSCL $\pm \mathrm{P}$ patients, and further demonstrated that patients with unilateral complete CLP and bilateral incomplete CLP were frequently more affected by dental anomalies. Moreover, our results demonstrate that dental anomalies should be considered during dental treatment planning of individuals affected by NSCL $\pm \mathrm{P}$.
\end{abstract}

Key words: Nonsyndromic cleft lip with or without palate, dental anomaly, tooth agenesis, microdontia. 


\section{Introduction}

Nonsyndromic cleft lip with or without cleft palate (NSCL \pm P) is the most common orofacial birth defect, with prevalence ranging from $0.36-1.54$ per 1.000 live births in Brazil $(1,2)$. The oral clefts and the development of tooth germs have close embryological association in terms of timing and anatomical position (3), with critical events related to teeth, lip and palate formation occurring almost simultaneously (4). Dental alterations are significantly more frequent in subjects born with oral clefts if compared to the general population (5-9). In the cleft area, agenesis of the maxillary lateral incisors is the most prevalent dental anomaly, which is probably resulted of local effects of cleft $(3,10,11)$. Supernumerary tooth are the second most common anomaly (12).

The aim of this study was to investigate the prevalence of dental anomalies inside the cleft area in a group Brazilian patients with NSCL \pm P.

\section{Material and Methods}

In this retrospective cross-sectional study, 897 clinical records and panoramic radiographs of individuals with $\mathrm{NSCL} \pm \mathrm{P}$ assisted at the Reference Center for Craniofacial Anomalies of the Santo Antonio Hospital, Salvador, Bahia, Brazil, were reviewed. Due to inability to accurately identify all dental anomalies, cases without complete dental history, with dental extraction, with previous orthodontic treatment and at an early age $(<12-$ year old) were excluded. Patients with cleft palate only (CPO) were not included. At this point, the study ended up with 178 cases. Subphenotypes were classified according to cleft extension - complete or incomplete, and laterality - unilateral or bilateral.

Radiographs with acceptable sharpness, contrast and density were assessed by a single calibrated examiner. The following anomalies were identified: tooth agenesis, giroversion,microdontia, supernumerary tooth, included/impacted tooth, ectopic tooth, dental transposition and accessory cuspid. Statistical analysis first comprised the description of the frequencies and types of dental anomalies. Association between cleft type and the prevalence of dental anomalies was assessed by chisquare test with a significance level set at $p \leq 0.05$.

Written informed consents were obtained and the study carried out with approval of the ethics committee of the Bahiana School of Medicine and Public Health, Salvador, Bahia, Brazil.

\section{Results}

Out of 178 patients with NSCL \pm P, 91 (51.1\%) corresponded to males and $87(48.9 \%)$ to females. The age of the patients ranged from 12 to 45 years old. Cleft lip and palate (CLP) was the most frequent type of oral cleft $(\mathrm{n}=135$, $75.9 \%)$, particularly unilateral complete $(\mathrm{n}=90,66.7 \%)$ and bilateral incomplete $(n=34,25.2 \%)$. The less frequent subtypes were unilateral incomplete CLP ( $\mathrm{n}=4,2.9 \%)$ and bilateral complete CLP ( $\mathrm{n}=7,5.2 \%)$. Cleft lip only (CLO) was found in 43 (24.1\%) patients, and unilateral incomplete $(\mathrm{n}=23,53.5 \%)$ and unilateral complete $(\mathrm{n}=15$, $34.9 \%$ ) were the extensions more common of CLO. In general, complete clefts $(63.5 \%)$ were more frequently observed than incomplete clefts, and unilateral (74.1\%) were more frequently observed than bilateral.

Dental anomalies were found in 157 patients, 35 (22.3\%) with CLO and 122 (77.7\%) with CLP. A single anomaly was identified in 21 individuals (11.8\%) and $157(88.2 \%)$ had multiple anomalies. Associations of agenesis and giroversion (30.3\%), followed by giroversion and microdontia $(16.0 \%)$ were the most frequent. Table 1 describes the distribution of the dental anomalies according to cleft extension. Individuals with tooth agenesis represented $47.1 \%$ of the sample, followed by those with giroversion (20\%) microdontia (15.5\%), impacted tooth $(7.5 \%)$, supernumerary tooth $(3.8 \%)$, transposition (3.4\%), ectopic tooth (2.3\%) and accessory cusp $(0.4 \%)$. Patients with unilateral complete CLP $(n=107)$ and bilateral incomplete CLP $(n=85)$ were the most affected. Concerning CLO, 25 dental anomalies

Table 1. Distribution of the dental anomalies according to cleft extension.

\begin{tabular}{|c|c|c|c|c|c|c|c|c|c|}
\hline \multirow[b]{2}{*}{ Cleft type } & \multicolumn{9}{|c|}{ Number of dental anomalies } \\
\hline & Total & $\begin{array}{c}\text { Tooth } \\
\text { agenesis }\end{array}$ & Giroversion & Microdontia & $\begin{array}{l}\text { Impacted } \\
\text { tooth }\end{array}$ & $\begin{array}{c}\text { Supernumerary } \\
\text { tooth }\end{array}$ & Transposition & $\begin{array}{c}\text { Ectopic } \\
\text { tooth }\end{array}$ & $\begin{array}{c}\text { Accessory } \\
\text { cusp }\end{array}$ \\
\hline \multicolumn{10}{|l|}{ Cleft lip only } \\
\hline Unilateral Complete & 18 & 2 & 5 & 9 & 0 & 1 & 1 & 0 & 0 \\
\hline Unilateral Incomplete & 25 & 6 & 8 & 7 & 2 & 1 & 1 & 0 & 0 \\
\hline Bilateral Complete & 2 & 0 & 0 & 2 & 0 & 0 & 0 & 0 & 0 \\
\hline Bilateral Incomplete & 6 & 0 & 4 & 1 & 0 & 1 & 0 & 0 & 0 \\
\hline \multicolumn{10}{|l|}{ Cleft lip and palate } \\
\hline Unilateral Complete & 107 & 62 & 15 & 13 & 7 & 2 & 4 & 3 & 1 \\
\hline Unilateral Incomplete & 5 & 0 & 3 & 2 & 0 & 0 & 0 & 0 & 0 \\
\hline Bilateral Complete & 17 & 7 & 3 & 0 & 3 & 3 & 1 & 0 & 0 \\
\hline Bilateral Incomplete & 85 & 48 & 15 & 7 & 8 & 2 & 2 & 3 & 0 \\
\hline Total & 265 & 125 & 53 & 41 & 20 & 10 & 9 & 6 & 1 \\
\hline
\end{tabular}


were observed in patients with unilateral incomplete and 18 were found in patients with unilateral complete. Agenesis was more frequent in unilateral complete FLP $(p<0.0001)$ and in bilateral complete CLP $(p=0.0002)$. Tooth agenesis $(p<0.0001)$, giroversion $(p<0.0001)$ and microdontia $(p<0.005)$ were significantly more frequent in CLP group than in CL group. Isolated tooth agenesis was more frequent than multiple agenesis $(p=0.001)$. The most affected teeth were the lateral incisors $(\mathrm{n}=110)$, central incisors $(\mathrm{n}=12)$ and canines $(\mathrm{n}=3)$.

Frequency of individuals with dental anomalies according to cleft extension is depicted in table 2. Individu- (between incisors and canines) in different extensions of the cleft. Out of the total, $35.7 \%$ of the patients presented multiple dental anomalies. The greatest frequency of agenesis was associated to giroversion (30.3\%) followed by giroversion and microdontia $(16.0 \%)$. Such associations have not been listed in literature. It is only found that microdontia outside affected area is associated to agenesis inside the cleft (7).

According to literature, the number of affected teeth increases with severity of the cleft phenotype $(5,6,12,15,16)$. The most extensive cleft type is bilateral complete CLP. The cleft breaches the maxilla in all its extension, from

Table 2. Frequency of individuals with dental anomalies according to cleft extension.

\begin{tabular}{|c|c|c|c|c|c|c|c|c|c|c|c|c|c|c|c|c|c|c|}
\hline \multirow[b]{3}{*}{ Cleft Type } & \multicolumn{18}{|c|}{ Number of patients (\%) } \\
\hline & \multicolumn{2}{|c|}{$\begin{array}{l}\text { Tooth } \\
\text { agenesis }\end{array}$} & \multicolumn{2}{|c|}{ Giroversion } & \multicolumn{2}{|c|}{ Microdontia } & \multicolumn{2}{|c|}{$\begin{array}{l}\text { Impacted } \\
\text { tooth }\end{array}$} & \multicolumn{2}{|c|}{$\begin{array}{l}\text { Supernumerary } \\
\text { tooth }\end{array}$} & \multicolumn{2}{|c|}{ Transposition } & \multicolumn{2}{|c|}{$\begin{array}{l}\text { Ectopic } \\
\text { tooth }\end{array}$} & \multicolumn{2}{|c|}{$\begin{array}{l}\text { Accessory } \\
\text { cusp }\end{array}$} & \multicolumn{2}{|c|}{$\begin{array}{c}\text { Multiple } \\
\text { anomalies* }\end{array}$} \\
\hline & $\mathrm{U}$ & A & $\mathrm{U}$ & A & $\mathrm{U}$ & A & $\mathrm{U}$ & A & $\mathrm{U}$ & A & $\mathrm{U}$ & A & $\mathrm{U}$ & A & $\mathrm{U}$ & A & $\mathrm{U}$ & A \\
\hline \multicolumn{19}{|l|}{ Cleft lip only } \\
\hline $\begin{array}{l}\text { Unilateral } \\
\text { Complete }\end{array}$ & $\begin{array}{c}13 \\
(86.7) \\
\end{array}$ & $\begin{array}{c}2 \\
(13.3) \\
\end{array}$ & $\begin{array}{c}10 \\
(66.7)\end{array}$ & $\begin{array}{c}5 \\
(33.3) \\
\end{array}$ & $\begin{array}{c}6 \\
(40.0) \\
\end{array}$ & $\begin{array}{c}9 \\
(60.0) \\
\end{array}$ & $\begin{array}{c}15 \\
(100)\end{array}$ & 0 & $\begin{array}{c}14 \\
(93.3)\end{array}$ & $\begin{array}{c}1 \\
(6.7)\end{array}$ & $\begin{array}{c}14 \\
(93.3) \\
\end{array}$ & $\begin{array}{c}1 \\
(6.7)\end{array}$ & $\begin{array}{c}15 \\
(100)\end{array}$ & 0 & $\begin{array}{c}15 \\
(100)\end{array}$ & 0 & $\begin{array}{c}3 \\
(20.0) \\
\end{array}$ & $\begin{array}{c}12 \\
(80.0)\end{array}$ \\
\hline $\begin{array}{l}\text { Unilateral } \\
\text { Incomplete }\end{array}$ & $\begin{array}{c}17 \\
(73.9) \\
\end{array}$ & $\begin{array}{c}6 \\
(26.1) \\
\end{array}$ & $\begin{array}{c}17 \\
(73.9) \\
\end{array}$ & $\begin{array}{c}6 \\
(26.1) \\
\end{array}$ & $\begin{array}{c}16 \\
(69.6) \\
\end{array}$ & $\begin{array}{c}7 \\
(30.0) \\
\end{array}$ & $\begin{array}{c}22 \\
(95.7)\end{array}$ & $\begin{array}{c}1 \\
(4.3) \\
\end{array}$ & $\begin{array}{c}22 \\
(95.7) \\
\end{array}$ & $\begin{array}{c}1 \\
(4.3) \\
\end{array}$ & $\begin{array}{c}22 \\
(95.7) \\
\end{array}$ & $\begin{array}{c}1 \\
(4.3) \\
\end{array}$ & $\begin{array}{c}23 \\
(100) \\
\end{array}$ & 0 & $\begin{array}{c}23 \\
(100) \\
\end{array}$ & 0 & $\begin{array}{c}4 \\
(17.4) \\
\end{array}$ & $\begin{array}{c}19 \\
(82.6) \\
\end{array}$ \\
\hline $\begin{array}{l}\text { Bilateral } \\
\text { Complete }\end{array}$ & $\begin{array}{c}1 \\
(100) \\
\end{array}$ & 0 & $\begin{array}{c}1 \\
(100) \\
\end{array}$ & 0 & 0 & $\begin{array}{c}1 \\
(100)\end{array}$ & $\begin{array}{c}1 \\
(100)\end{array}$ & 0 & $1(100)$ & 0 & $\begin{array}{c}1 \\
(100) \\
\end{array}$ & 0 & $\begin{array}{c}1 \\
(100)\end{array}$ & 0 & $\begin{array}{c}1 \\
(100) \\
\end{array}$ & 0 & 0 & $\begin{array}{c}1 \\
(100) \\
\end{array}$ \\
\hline $\begin{array}{l}\text { Bilateral } \\
\text { Incomplete }\end{array}$ & $\begin{array}{c}4 \\
(100)\end{array}$ & 0 & $\begin{array}{c}2 \\
(50.0)\end{array}$ & $\begin{array}{c}2 \\
(50.0)\end{array}$ & $\begin{array}{c}3 \\
(75.0) \\
\end{array}$ & $\begin{array}{c}1 \\
(25.0) \\
\end{array}$ & $\begin{array}{c}4 \\
(100)\end{array}$ & 0 & $\begin{array}{c}3 \\
(75.0)\end{array}$ & \begin{tabular}{c|}
1 \\
$(25.0)$
\end{tabular} & $\begin{array}{c}4 \\
(100)\end{array}$ & 0 & $\begin{array}{c}4 \\
(100)\end{array}$ & 0 & $\begin{array}{c}4 \\
(100)\end{array}$ & 0 & 0 & $\begin{array}{c}4 \\
(100)\end{array}$ \\
\hline \multicolumn{19}{|l|}{$\begin{array}{l}\text { Cleft lip and } \\
\text { palate }\end{array}$} \\
\hline $\begin{array}{l}\text { Unilateral } \\
\text { Complete }\end{array}$ & $\begin{array}{c}34 \\
(37.8)\end{array}$ & $\begin{array}{c}56 \\
(62.2)\end{array}$ & $\begin{array}{c}76 \\
(84.4)\end{array}$ & $\begin{array}{c}14 \\
(15.6)\end{array}$ & $\begin{array}{c}77 \\
(85.6)\end{array}$ & $\begin{array}{c}13 \\
(14.4)\end{array}$ & $\begin{array}{c}84 \\
(93.3)\end{array}$ & $\begin{array}{c}6 \\
(6.7)\end{array}$ & $\begin{array}{c}88 \\
(97.8)\end{array}$ & $\begin{array}{c}2 \\
(2.2)\end{array}$ & $\begin{array}{c}86 \\
(95.6)\end{array}$ & $\begin{array}{c}4 \\
(4.4)\end{array}$ & $\begin{array}{c}87 \\
(96.7)\end{array}$ & $\begin{array}{c}3 \\
(3.3)\end{array}$ & $\begin{array}{c}89 \\
(98.9)\end{array}$ & $\begin{array}{c}1 \\
(1.1)\end{array}$ & $\begin{array}{c}17 \\
(18.9)\end{array}$ & $\begin{array}{c}73 \\
(81.1)\end{array}$ \\
\hline $\begin{array}{l}\text { Unilateral } \\
\text { Incomplete }\end{array}$ & $\begin{array}{c}4 \\
(100)\end{array}$ & 0 & $\begin{array}{c}2 \\
(50.0)\end{array}$ & $\begin{array}{c}2 \\
(50.0)\end{array}$ & $\begin{array}{c}2 \\
(50.0) \\
\end{array}$ & $\begin{array}{c}2 \\
(50.0) \\
\end{array}$ & $\begin{array}{c}4 \\
(100)\end{array}$ & 0 & $4(100)$ & 0 & $\begin{array}{c}4 \\
(100)\end{array}$ & 0 & $\begin{array}{c}4 \\
(100)\end{array}$ & 0 & $\begin{array}{c}4 \\
(100)\end{array}$ & 0 & 0 & $\begin{array}{c}4 \\
(100)\end{array}$ \\
\hline $\begin{array}{l}\text { Bilateral } \\
\text { Complete }\end{array}$ & $\begin{array}{c}3 \\
(42.9) \\
\end{array}$ & $\begin{array}{c}4 \\
(57.1) \\
\end{array}$ & $\begin{array}{c}4 \\
(57.1)\end{array}$ & $\begin{array}{c}3 \\
(42.9) \\
\end{array}$ & $\begin{array}{c}7 \\
(100)\end{array}$ & 0 & $\begin{array}{c}5 \\
(71.4)\end{array}$ & $\begin{array}{c}2 \\
(28.6) \\
\end{array}$ & $\begin{array}{c}6 \\
(85.7) \\
\end{array}$ & \begin{tabular}{c|}
1 \\
$(14.3)$
\end{tabular} & $\begin{array}{c}6 \\
(85.7) \\
\end{array}$ & $\begin{array}{c}1 \\
(14.3)\end{array}$ & $\begin{array}{c}7 \\
(100) \\
\end{array}$ & 0 & $\begin{array}{c}7 \\
(100)\end{array}$ & 0 & 0 & $\begin{array}{c}7 \\
(100) \\
\end{array}$ \\
\hline $\begin{array}{l}\text { Bilateral } \\
\text { Incomplete }\end{array}$ & $\begin{array}{c}7 \\
(20.6) \\
\end{array}$ & $\begin{array}{c}27 \\
(79.4) \\
\end{array}$ & $\begin{array}{c}23 \\
(67.6) \\
\end{array}$ & $\begin{array}{c}11 \\
(32.4) \\
\end{array}$ & $\begin{array}{c}29 \\
(85.3) \\
\end{array}$ & $\begin{array}{c}5 \\
(14.7) \\
\end{array}$ & $\begin{array}{c}28 \\
(82.4) \\
\end{array}$ & $\begin{array}{c}6 \\
(17.6) \\
\end{array}$ & $\begin{array}{c}33 \\
(97.1) \\
\end{array}$ & $\begin{array}{c}1 \\
(2.9) \\
\end{array}$ & \begin{tabular}{c|}
32 \\
$(94.1)$ \\
\end{tabular} & $\begin{array}{c}2 \\
(5.9) \\
\end{array}$ & $\begin{array}{c}32 \\
(94.1) \\
\end{array}$ & $\begin{array}{c}2 \\
(5.9) \\
\end{array}$ & \begin{tabular}{c|}
34 \\
$(100)$ \\
\end{tabular} & 0 & \begin{tabular}{c|}
1 \\
$(2.9)$ \\
\end{tabular} & $\begin{array}{c}33 \\
(97.1) \\
\end{array}$ \\
\hline Total & $\begin{array}{c}83 \\
(46.6)\end{array}$ & $\begin{array}{c}95 \\
(53.4)\end{array}$ & $\begin{array}{c}135 \\
(75.8)\end{array}$ & $\begin{array}{c}43 \\
(24.2)\end{array}$ & $\begin{array}{c}140 \\
(78.6)\end{array}$ & $\begin{array}{c}38 \\
(21.4)\end{array}$ & $\begin{array}{c}163 \\
(91.6)\end{array}$ & $\begin{array}{c}15 \\
(8.4)\end{array}$ & $\begin{array}{c}171 \\
(96.1)\end{array}$ & $\begin{array}{c}7 \\
(3.9)\end{array}$ & $\begin{array}{c}169 \\
(94.9)\end{array}$ & $\begin{array}{c}9 \\
(5.1)\end{array}$ & $\begin{array}{c}173 \\
(97.2)\end{array}$ & $\begin{array}{c}5 \\
(2.8)\end{array}$ & $\begin{array}{c}177 \\
(99.4)\end{array}$ & $\begin{array}{c}1 \\
(0.6)\end{array}$ & \begin{tabular}{c|}
21 \\
$(11.8)$
\end{tabular} & $\begin{array}{c}157 \\
(88.2)\end{array}$ \\
\hline
\end{tabular}

*Multiple anomalies were considered when individuals presented more than one dental anomaly. U: unaffected. A: affected.

als with unilateral complete CLP $(p<0.0001)$, bilateral complete CLP $(p=0.0002)$ and bilateral incomplete CLP $(p<0.0001)$ were more affected by tooth agenesis than subjects with other cleft types. Those with unilateral complete CLP were more affected by multiple anomalies $(p=0.016)$ and individuals with unilateral complete $\mathrm{CL}$ were more affected by microdontia $(p<0.0001)$.

\section{Discussion}

Oral clefts may present variable severity degree according to its extension, causing various anatomical and functional alterations $(13,14)$. In this study we investigated the prevalence of dental anomalies inside cleft area the lip to the uvula. We expected to find in this phenotype, a greater frequency of multiple dental anomalies and a greater number of affected teeth. However, our results revealed that patients with unilateral complete CLP were more affected by multiple dental anomalies ( $p=0.016)$ than those with other types of cleft were. Regarding the number of affected teeth, the greatest rates were also found in unilateral complete CLP $(n=114)$ if compared to bilateral complete CLP $(n=17)$. Although the sample of individuals with bilateral complete CLP is small, only seven patients such results suggest that disturbed dental development does not necessarily increase with the cleft severity. In Brazilian population a 
study showed that patients with CLP have the highest rates of multiple dental anomalies out of the cleft area, if compared to other subphenotypes (7).

The frequency of tooth agenesis, both in and outside the cleft region, is significantly increased in persons with clefts compared with the control population $(6,7,9,17,18)$. Multiple factors have been suggested to justify dental agenesis close to affected area. The osseous defect caused by the cleft (10), congenital or surgery-caused low blood supply, or even low ectomesenchymal supply $(12,19)$. Our results revealed agenesis in $45.9 \%$ of cleft patients and was more frequent in unilateral complete CLP $(p<0.0001)$, CLP bilateral complete $(p=0.0002)$ and bilateral incomplete CLP $(p<0.0001)$. Stahl et al. 2006 , also found prevalence of agenesis in $46.6 \%$ of European cleft individuals. In literature, we found high frequency of agenesis in bilateral or unilateral clefts of lip, alveolus, and palate $(52.6 \%$ and $52.6 \%)(3,12)$. Our research pointed a total of 125 missing teeth from which the maxillary lateral incisor was the most affected one $(p<0.0001)$, found in the most aggressive cleft phenotypes. These findings are explained by the anatomic proximity of lateral incisor to the cleft $(7,8,10,20)$. Outside the cleft area, lateral incisors are also the most affected teeth $(5,8,16)$, and more frequent in individuals with unilateral complete CLP (7).

Researches about the prevalence of giroversion in cleft individuals are scarce. Our results show that giroversion was associated to CLP $(p=0.005)$ group, and more frequent in individuals with unilateral incomplete CLP $(50.0 \%)$ and bilateral complete (42.9\%). Tortora et al. (17) have showed that giroversion occurred in lateral and central incisors, in or outside the cleft, in individuals with unilateral or bilateral CLP. Other studies reported giroversion in anterosuperior area, though without association with the cleft type. $(21,22)$.

Microdontia is reported as a partial expression of the same genetic flaw that defines agenesis (23). According to Werner and Harris (24) tooth size in unilateral CLP patients is significantly smaller than in noncleft individuals, suggesting that the compromised growth potential of CLP patients may affect tooth development. In our study, microdontia has been found in $18.4 \%$ of the sample and it was more frequent in unilateral complete CL, $(p<0.0001)$. Outside the cleft area, the prevalence of microdontia has greater rates and reach $48.2 \%(25,26)$. In a group of Brazilian patients with NSCL/P, the frequency was significantly higher than those observed in general population $(9,18)$.

Impacted teeth were observed in $7.2 \%$ of the sample with higher frequency in individuals with bilateral complete (28.6\%) and incomplete (17.6\%) CLP. In the Brazilian population, this anomaly has been reported outside the cleft area in $8.8 \%$ of the individuals, (9). Ackan et al. (21) showed frequencies of impacted teeth varying from 1.9 to $29.2 \%$, in the anterior region and premolars in CLP groups, with higher rates on the cleft side. Dental transposition is an uncommon dental alteration with a genetic origin that has been associated with other severe dental anomalies $(27,28)$. Outside cleft area, such anomaly has been associated with tooth agenesis (18). In our study, dental transposition reached $4.3 \%$ and was more associated with bilateral complete CLP (14.3\%) and incomplete CLP (5.9\%). Wu et al. (26) also described dental transpositions associated with complete CLP, but in lower percentage than observed in our findings (10.6\%). Supernumerary teeth were observed in only $3.4 \%$ of the sample. Kim and Baek (19) found 5.4\% and Tortora et al. (17) $7.3 \%$. Other studies related the presence of supernumerary teeth in the cleft area as the second most common dental anomaly $(12,29)$. Outside cleft area, supernumerary teeth were quite often associated with unilateral complete CLP (7). Our results showed that $25 \%$ of the individuals with bilateral incomplete CL and $14.3 \%$ with bilateral complete CLP had supernumerary teeth. Wu et al. (26) reported $15 \%$ of prevalence among patients with CL without commitment of the alveolar edge and $13.2 \%$ in individuals with bilateral CLP. There are two hypothesis about supernumerary teeth occurrence in cleft patients. The first suggests that the odontogenic region of the lateral incisor comes from the medial nasal and maxillary processes, and the nonfusion of these two processes results in two separated lateral incisors (12). Another hypothesis is that supernumerary teeth come from the postfusion rupture of the cleft in the lateral incisor area, and the tooth germ of the lateral incisor is split in two separate teeth (26).

Ectopic teeth were found in $2.4 \%$ of the sample and were registered in $3.3 \%$ of the patients with unilateral complete CLP and $5.9 \%$ of individuals with bilateral incomplete CLP. Ectopic teeth prevalence has not been documented at anterior portion of maxillary cleft patients. Out of the cleft zone, this anomaly is considered more prevalent in NSCL \pm P patients than those observed in the general population (9).

As observed in these findings, we concluded that agenesis is the most prevalent dental anomaly found in $\mathrm{NSCL} \pm \mathrm{P}$ patients inside the cleft area and it is associated to wide-ranged subphenotypes. Other disorders of number, size, eruption and location were also observed. However, as oral clefts have a multifactorial etiology, we should not ignore that genetic and environmental factors may influence dental anomalies development, even inside the cleft area. Our results demonstrate that dental anomalies should be considered during dental treatment planning of individuals affected by NSCL \pm P. 


\section{References}

1. Martelli-Junior H, Porto LV, Martelli DR, Bonan PR, Freitas AB, Della Coletta R. Prevalence of nonsyndromic oral clefts in a reference hospital in the state of Minas Gerais, Brazil, between 20002005. Braz Oral Res. 2007;21:314-7.

2. Rodrigues K, Sena MF, Roncalli AG, Ferreira MA. Prevalence of orofacial clefts and social factors in Brazil. Braz Oral Res. 2009;23:38-42.

3. Stahl F, Grabowski R, Wigger K. Epidemiology of Hoffmeister's "genetically determined predisposition to disturbed development of the dentition" in patients with cleft lip and palate. Cleft Palate Craniofac J. 2006;43:457-65.

4. Hovorakova M, Lesot H, Peterková R, Peterka M. Origino of the deciduous upper lateral incisor and its clinical aspects. J Dent Res. 2006;85:167-71

5. Shapira Y, Lubit E, Kuftinec MM. Tooth agenesis in children with various types of clefts. Angle Orthod. 2000;70:16-21.

6. Slayton RL, Williams L, Murray JC, Wheeler JJ, Lidral AC, Nishimura CJ. Genetic association studies of cleft lip and/or palate with hypodontia outside the cleft region. Cleft Palate Craniofac J. 2003;40:274-9.

7. Letra A, Menezes R, Granjeiro JM, Vieira AR. Defining subphenotypes for oral clefts based on dental development. J Dent Res. 2007;86:986-91.

8. Menezes R, Vieira AR. Dental anomalies as part of the cleft spectrum. Cleft Palate Craniofac J. 2008;45:414-9.

9. Paranaíba LMR, Coletta RD, Swerts MSO, Quintino RP, Barros LM, Martelli-Júnior H. Prevalence of Dental Anomalies in Patients With Nonsyndromic Cleft Lip and/or Palate in a Brazilian Population. Cleft Palate Craniofac J. 2013;50:400-5.

10. Camporesi M, Baccetti T, Marinelli A, Defraia E, Franchi L. Maxillary dental anomalies in children with cleft lip and palate: a controlled study. Int J Paediatr Dent. 2010;20:442-50.

11. Tanure PN, Oliveira CAGR, Maia, LC, Vieira AR, Granjeiro JM. Prevalence of dental anomalies in nonsyndromic individuals with cleft lip and palate: A Systematic Review and Meta-analysis. Cleft Palate Craniofac J. 2012;49:194-200.

12. Tsai TP, Huang CS, Huang CC, See LC. Distribution patterns of primary and permanent dentition in children with unilateral complete cleft lip and palate. Cleft Palate Craniofac J. 1998;35:154-60.

13. Lourenço Ribeiro L, Teixeira Das Neves L, Costa B, Ribeiro Gomide M. Dental anomalies of the permanent lateral incisors and prevalence of hypodontia outside the cleft area in complete unilateral cleft lip and palate. Cleft Palate Craniofac J. 2003;40:172-5.

14. Tereza GP, Carrara CF, Costa B. Tooth abnormalities of number and position in the permanent dentition of patients with complete bilateral cleft lip and palate. Cleft Palate Craniofac J. 2010;47:247-52.

15. Dewinter G, Quirynen M, Heidbüchel K, Verdonck A, Willems G, Carels C. Dental abnormalities, bone graft quality, and periodontal conditions in patients with unilateral cleft lip and palate at different phases of orthodontic treatment. Cleft Palate Craniofac J. 2003;40:343-50.

16. da Silva AP, Costa B, de Carvalho Carrara CF. Dental anomalies of number in the permanent dentition of patients with bilateral cleft lip: radiographic study. Cleft Palate Craniofac J. 2008;45:473-6.

17. Tortora C, Meazzini MC, Garattini G, Brusati R. Prevalence of abnormalities in dental structure, position, and eruption pattern in a population of unilateral and bilateral cleft lip and palate patients. Cleft Palate Craniofac J. 2008;45:154-62.

18. Kuchler E, Motta L, Vieira A, Granjeiro J. Side of dental anomalies and taurodontism as potential clinical markers for cleft subphenotypes. Cleft Palate Craniofac J. 2011;48:103-8.

19. Kim N, Baek S. Cleft sidedness and congenitally missing or malformed permanente maxillary lateral incisors in Korean patients with unilateral cleft lip and alveolus or unilateral cleft lip and palate. Am J Orthod Dentofacial Orthop. 2006;130:752-8.

20. Ranta R. A review of tooth formation in children with cleft lip/ palate. Am J Orthod Dentofacial Orthop. 1986;90:11-8.
21. Akcam MO, Evirgen S, Uslu O, Memikoglu UT. Dental anomalies in individuals with cleft lip and/or palate. Eur J Orthod. 2010;32:20713

22. Eslami N, Majidi MR, Aliakbarian M, Hasanzadeh N. Prevalence of dental anomalies in patients with cleft lip and palate. J Craniofac Surg. 2013;24:1695-8.

23. Lyngstadaas SP, Nordbo H, Gedde-Dahl T Jr, Thrane OS. On the genetics of hypodontia and microdontia: synergism or allelism of major genes in a Family with six affected members. Journal of medical genetics. 1996;33:137-42.

24. Werner SP, Harris EF. Odontometrics of the permanent teeth in cleft lip and palate: systemic size reduction and amplified asymmetry. Cleft Palate J. 1989;26:36-41.

25. Al Jamal GA, Hazza'a AM, Rawashdeh MA. Prevalence of dental anomalies in a population of cleft lip and palate patients. Cleft Palate Craniofac J. 2010;47:413-20.

26. Wu TT, Chen PH, Lo LJ, Cheng MC, Ko EW. Caracteristics and distribuition of dental anomalies in patients with cleft. Chang Gung Med J. 2011;34:306-14.

27. Peck S, Peck L, Kataja M. Concomitant occurrence of canine malposition and tooth agenesis: evidence of orofacial genetic fields. Am J Orthod Dentofacial Orthop. 2002;122:657-60.

28. Ely NJ, Sherriff M, Cobourne MT. Dental transposition as a disorder of genetic origin. Eur J Orthod. 2006;28:145-51.

29. Hellquist R, Linder-Aronson S, Norling M, Ponten B, Stenberg T. Dental abnormalities in patients with alveolar cleft, operated upon with or without primary perioplasty. Eur J Orthod. 1979;1:169-80

\section{Acknowledgements}

We thank Santo Antonio Hospital, Salvador, Bahia and especially Mrs. Maria Luiza Miranda Marques for her assistance. This work was supported by grants from the State of Bahia Research Foundation- FAPESB, Bahia, Brazil (00007/014) and the National Council for Scientific and Technological Development - CNPq, Brasília, Brazil (484292/2013-7). There is no conflict of interest. 